\title{
Social media attitudes among vocational school students
}

\author{
Ezgi Pelin Yildiz ${ }^{1}$, Metin Çengel², Ayşe Alkan ${ }^{3}$ \\ ${ }^{1}$ Department of Computer Programming, Kafkas University Kazım Karabekir Vocational School of Technical \\ Sciences, Turkey \\ ${ }^{2}$ Department of Computer Programming, Sakarya University of Applied Sciences Hendek Vocational High \\ School, Turkey \\ ${ }^{3}$ Samsun Provincial Directorate of National Education, Turkey
}

\begin{abstract}
Article Info
Article history:

Received Jun 11, 2019

Revised Aug 12, 2019

Accepted Aug 29, 2019

\section{Keywords:}

Attitude

Social media

Social network communication tools

Vocational school students

ABSTRACT

The rapid developments in communication technologies in recent years, especially the introduction of the internet into our daily lives, have brought many changes in social, economic and cultural life.One of these changes; social media communication tools that enter our lives rapidly.Social media has become an indispensable part of our lives with the increasing number of users. Researches show that young people especially university students frequently use social media communication tools. In this study, social media attitudes of Vocational High School students were investigated and in this context, 502 students studying at Sakarya University and Kafkas University Vocational High Schools were studied. Social Media Attitude Scale developed by Otrar and Arginwas used to determine the social media attitudes of Vocational School students.The scale consists of 23 items. Relational screening method was used in the research. Necessary analyzes were performed with SPSS 24 program and mean and standard deviation values of the scale items were calculated.Two groups $t$ test, one-way Anova test and Post-Hoc Scheffe test were used to correlate social media attitudes with demographic data. In conclusion, there was no significant difference between students' social media attitudes and gender, department, class, internet usage time demographic data; however, there was a positive and significant relationship between social media attitudes and internet connection year and social media usage hours.
\end{abstract}

Copyright (c) 2019 Institute of Advanced Engineering and Science. All rights reserved.

\section{Corresponding Author:}

Ezgi Pelin Yildiz,

Department of Computer Programming,

Kafkas University Kazım Karabekir Vocational School of Technical Sciences,

Kafkas Üniversitesi Rektörlüğü (36100) Merkez/KARS, Turkey

Email: yildizezgipelin@gmail.com

\section{INTRODUCTION}

The rapid development of technology and widespread use of the Internet have led to changes in the communication process. Today, social media, which is one of the most used communication tools, is used by a wide audience, especially the young population. Social media; they are online communication channels that can be developed, interactive, hosting communities and connecting communities [1,2]. Erkul [3] also defines social media as an environment where the content is completely determined by individuals, where individuals can share, interact and discuss with each other without limitation of time and space, and they can communicate interactively through various applications. Similarly, Comm and Burge [4] and Kim et al. [5] defines social media as content created by users. In addition, it is stated that social media provides opportunities for people to reflect themselves, to form communities, to create an environment of cooperation and sharing [6]. Paul and Dredze [7] include social media platforms; it defines people's instant emotions, thoughts, feelings and any details in their lives as online environments where they can be accessed via the 
internet. Akar [8] stated that most or all types of online media have common characteristics such as participation, openness, mutual communication, community, and connectedness.

Erkul [3] states that social media differs from other applications due to the fact that it is independent of the publisher. There is no time and space limitation, the opportunity for the user to share content, and the interaction between users.

Dikme [9] examined the social media usage habits of university students in communication and daily life, and in this context, the habits of Kadir Has University students using social media were investigated. As a result, it was determined that the majority of students were active and active users of social media and the majority of the students followed facebook social network more than other social networks.

Üksel [10] presented a study aimed to determine the social media use motivation of Sakarya University students within the framework of uses and satisfaction theory. At the end of the study, it was revealed that the majority of university students have been using social media for 5 years or more and they use social media daily at or below 120 minutes. However, when the relationship between social media usage time and gender was examined, it was found that males had been using social media for a longer time than women. In addition, the trust question was asked to determine the trust level of the participants in the social media, and as a result of the descriptive statistical analysis, it was concluded that the participants had moderate trust in the social media.

Tutgun-Unal [11] conducted a research with university students on social media addiction. According to gender comparisons, it was found that women were more engaged in social media and received more emotional support from social media than men, whereas men were in conflict with social media, in other words, they were negatively affected.

With the development of Web 2.0 technologies, different internet platforms have started to be used today.Social networking sites are also one of the most popular platforms [12].Social media tools are grouped into social networks, forums, blogs, wikis, content communities, podcasts, and microblogs [13].Today, the most used social networking sites facebook, twitter, foursquare, instagram, snapchat, whatsapp, swarm, linkedln and youtube can be added.

With the development of internet technologies and the emergence of social media, the use of social media is also increasing day by day and is becoming part of our daily lives [14].As a result of the study conducted by Aydin [15], a significant relationship between the frequency of internet use and the use of social networking tools supports this view.It is stated that individuals acquire various motivations such as entertainment, leisure time, information, stress relief, relaxation and socialization, communication and escape by using social media [16-18].

In addition to accessing and sharing information, social media provides advantages to users in many areas such as entertainment, communication, commerce, following the agenda and socialization but brings some risks.In addition to addiction, excessive use of social media has negative effects such as sleep disorders, physical pain such as hands, head, neck, back and eyes [19].Also, it is possible to say that new psychological problems such as stalking (FOMO), attention deficit and hyperactivity disorder and narcissism have emerged according to the usage of social media. [20].In addition, there is a fear of missing self-esteem (FOMO) in social media users [21].

\section{RESEARCH METHOD}

In this research, relational survey model was used. Relational screening model; It is a research model aiming to determine the existence and/or degree of change together between two or more variables [22].

\subsection{Data collection tool}

In this study, Social Media Attitude Scale developed by Otrar and Argin [1] was used to determine social media attitudes of Vocational School students. The scale consists of 23 items.

\subsection{Data collection}

In this study, in order to determine social media attitudes of Vocational School students, a total of $5021^{\text {st }}$ and $2^{\text {nd }}$ grade students studying at various departments of Sakarya University and Kafkas University Vocational High Schools (computer programming, electrical, electronics, construction, machinery, accounting, business). Of the 502 students, 345 were women and 157 were men.

\section{RESULTS AND DISCUSSION}

In this section, the results of the analysis of the responses to the applied scale are given. 


\subsection{Demographic data}

Demographic data of the research; gender, department and class information is given below verbally. According to this;

\subsubsection{Gender}

The study group of the study consists of 345 female and 157 male students.

\subsubsection{Department}

255 of them are computer programming, 54 of them are electrical, 23 of them are electronics, 66 of them are construction, 49 of them are machines, 32 of them are accounting and 23 of them are students of management department.

\subsubsection{Classroom}

326 of the students in the study group are $1^{\text {st }}$ grade and 176 of them are $2^{\text {nd }}$ grade students.

\subsubsection{Utilizing social networks}

428 of the students participating in the research stated that they use social media networks, while 74 stated that they did not.

\subsubsection{Device to connect to the internet}

Table 1 describes that the majority of students use "mobie phone" to connect to the Internet. This result is important in terms of the place of mobile phones in our lives. In addition, "PDAs"are another device connected to the internet.

Table 1. Device to connect to the internet

\begin{tabular}{lcc}
\hline Device to Connect to the internet & $\mathrm{f}$ & $\%$ \\
\hline Computer-tablet & 87 & 17.3 \\
Mobile Phone & 411 & 81.9 \\
Other & 4 & .8 \\
Total & 502 & 100 \\
\hline
\end{tabular}

\subsubsection{Number of social network memberships}

The frequency (f) and percentage (\%) students of the study group are presented in Table 2 shows that the majority of the students have more than one membership in social networks. According to the same table, the presence of students with more than 6 social network members is also noteworthy.

\begin{tabular}{lcc}
\multicolumn{3}{l}{ Table 2. Number of social network memberships } \\
\hline Number of Social Network Memberships & f & $\%$ \\
\hline 1 & 101 & 20.1 \\
2 & 114 & 22.7 \\
3 & 89 & 17.7 \\
4 & 79 & 15.7 \\
5 & 38 & 7.6 \\
6 & 8 & 1.6 \\
$6+$ & 73 & 14.5 \\
Total & 502 & 100 \\
\hline
\end{tabular}

\subsubsection{Purpose of internet use most}

The frequency (f) and percentage (\%) students of the study group are presented in Table 3. According to Table 3, the aim of students to use the internet the most; social networks. Apart from these, game-entertainment, research-homework have been put forward as the purposes of using the internet the most.

Table 3. Purpose of internet use most

\begin{tabular}{lcc}
\hline Purpose of internet use most & $\mathrm{f}$ & $\%$ \\
\hline Social network & 328 & 65.3 \\
Games \& Entertainment & 127 & 25.3 \\
Research-Homework & 41 & 8.2 \\
Other & 6 & 1.2 \\
Total & 502 & 100 \\
\hline
\end{tabular}




\subsubsection{Internet usage time}

The frequency (f) and percentage (\%) students of the study group are presented in Table 4.

When Table 4 is examined, the frequency of internet usage hours of the students; 5 hours or more. This result brings to mind the internet addiction.

Table 4. Internet usage time

\begin{tabular}{lcc}
\hline Internet Usage Time & $\mathrm{f}$ & $\mathbf{\%}$ \\
\hline 1 hour and less & 21 & 4.2 \\
1-3 hours & 130 & 25.9 \\
3-5 hours & 172 & 34.3 \\
5 hours and more & 179 & 35.7 \\
Total & 502 & 100 \\
\hline
\end{tabular}

\subsubsection{Year of internet connection}

The frequency (f) and percentage (\%) students of the study group are presented in Table 5. According to Table 5, majority of respondent has the frequency of year of students to have internet connection are more than five years.

Table 5. Year of internet connection

\begin{tabular}{lcc}
\hline Year of Internet Connection & $\mathrm{f}$ & $\mathbf{\%}$ \\
\hline 1 & 9 & 1.8 \\
2 & 55 & 11.0 \\
3 & 111 & 22.1 \\
4 & 2 & .4 \\
$5+$ & 325 & 64.7 \\
Total & 502 & 100 \\
\hline
\end{tabular}

\subsubsection{Social media usage hours}

The frequency (f) and percentage (\%) students of the study group are presented in Table 6.

When Table 6 is examined, the frequency of social media usage hours of students is determined as four hours or more. This result brings to mind the social media addiction.

Table 6. Social media usage hours

\begin{tabular}{lcc}
\hline Social Media Usage Hours & $\mathrm{f}$ & $\%$ \\
\hline 1 & 90 & 17.9 \\
2 & 99 & 19.7 \\
3 & 135 & 26.9 \\
$4+$ & 178 & 35.5 \\
Toplam & 502 & 100 \\
\hline
\end{tabular}

\subsubsection{Social media attitude scale items ans mean standard deviation values}

The Table 7 shows the items of social media attitude scale and average and standard deviation values.According to this; score limits used in interpretation of results; Strongly Disagree: 1.00-1.79; I disagree:1.80-2.59; Undecided: 2.60-3.39; I agree: 3.40-4.19; Strongly Agree: 4.20-5.00Buyukozturk [23] values have been accepted. In this context, since the overall average of all items for the scale was 2.83 , it was understood that the students' responses generally focused on the "undecided" option. When the items of the scale were compared, the item with the highest mean; "I like to share the posts I see on social media sites with my friends"; and the lowest item was "I think social media sites have taken me away from my family". 
Table 7. Social media attitude scale items and mean and standard deviation values

\begin{tabular}{|c|c|c|}
\hline Items and Factor & $X$ & SD \\
\hline I want my friends to notice me through social media sites. & 2.74 & 1.355 \\
\hline I feel that I have gained a new personality through social media sites. & 2.44 & 1.307 \\
\hline I don't think social media sites are driving me away from my friends. & 2.65 & 1.270 \\
\hline I like to share the posts I see on social media sites with my friends. & 3.55 & 1.230 \\
\hline I like to comment on content on social media sites. & 3.13 & 1.272 \\
\hline I like to share articles, videos, music, etc. on social media sites. & 3.21 & 1.378 \\
\hline I think social media sites have taken me away from my family. & 2.38 & 1.319 \\
\hline I think that I have survived my loneliness through social media sites. & 2.54 & 1.291 \\
\hline I like to follow my teachers on social media sites. & 2.59 & 1.305 \\
\hline I like it when my teachers follow what I write. & 2.58 & 1.330 \\
\hline I can't spend enough time with my family because of social media sites. & 2.51 & 1.311 \\
\hline I like my shares being liked by my friends. & 3.29 & 1.312 \\
\hline I think that I can reach people with common interests and goals through social media sites. & 3.23 & 1.263 \\
\hline I can't spend enough time on other social activities because of social media sites. & 2.75 & 1.295 \\
\hline I am happy to spend time on social media sites. & 3.25 & 1.195 \\
\hline I can express my feelings more easily through social media sites to my special interest friend. & 2.99 & 1.355 \\
\hline I like to be aware of the events organized through social media sites. & 3.26 & 1.203 \\
\hline I think I will have more friends thanks to social media sites. & 2.56 & 1.296 \\
\hline The fact that my teachers follow me on social media sites makes me feel valuable. & 2.71 & 1.324 \\
\hline I think that I need to be respected thanks to social media sites. & 2.49 & 1.308 \\
\hline I am happy that my friends comment on my posts. & 2.99 & 1.308 \\
\hline I cannot pay enough attention to my classes because of social media sites. & 2.86 & 1.372 \\
\hline I can't spend enough time with my friends because of social media sites. & 2.49 & 1.337 \\
\hline Total & 2.83 & 1.302 \\
\hline
\end{tabular}

\subsection{Relating social media attitudes of vocational school students with demographic data}

In this section, social media attitudes of Vocational High School students have demographic data; gender, department, class, internet usage time, internet connection year, social media usage time variables.

\subsubsection{By gender}

The Effect of Social Media Attitudes of Vocational School Students on Gender Variable

According to the results of two independent groups $t$ test; it was concluded that social media attitudes of Vocational High School students had no significant effect on gender $(p>0.05)$.

\subsubsection{By department}

The Effect of Social Media Attitudes of Vocational School Students on Department Variable

According to the results of One-Way Anova test; it was concluded that social media attitudes of Vocational High Schoolstudents had no significant effect according to department variable ( $\mathrm{p}>0.05)$.

\subsubsection{By classroom}

The Effect of Social Media Attitudes of Vocational School Students on Classroom Variable

According to the One-Way Anova test when Table 8 is examined; it was concluded that social media attitudes of Vocational High Schoolstudents did not have a significant effect according to class variable $(\mathrm{p}>0.05)$.

\subsubsection{Internet usage time}

Table 8 describes the results of the One-Way Anova test. It was concluded that social media attitudes of Vocational High School students did not have a significant effect on internet usage time variable $(\mathrm{p}<0.05)$.

Table 8 . The effect of social media attitudes of vocational school students on internet usage time variable

\begin{tabular}{llcccc}
\hline Source of variance & Sum of Squares & sd & Squares Per & F & P \\
\hline Intergroup & 4.927 & 4 & 1.642 & 2.839 & .068 \\
Intra Group & 287.533 & 497 & .579 & & \\
Total & 292.459 & 501 & & & \\
\hline
\end{tabular}

\subsubsection{Internet connection year}

According to the One-Way Anova test when Table 9 is examined; it was concluded that social media attitudes of Vocational High School students had a significant effect on the internet connection year variable $(\mathrm{p}<0.05)$. 
Table 9. The effect of social media attitudes of vocational school students on internet

\begin{tabular}{lccccc}
\multicolumn{6}{c}{ connection year variable } \\
\hline Source of variance & Sum of Squares & sd & Squares Per & F & P \\
\hline Intergroup & 11.521 & 4 & 2.880 & 5.085 & .000 \\
Intra Group & 280.938 & 497 & .566 & & \\
Total & 292.459 & 501 & & & \\
\hline
\end{tabular}

When Table 10 is examined, according to Scheffe test results; when the internet connection year was compared, it was found that there was a significant difference between the years of internet connection between 1 year and between 5 and 5 years and above $(\mathrm{p}<0.05)$.

Table 10. Comparison of sub-groups by internet connection year

\begin{tabular}{lllll}
\hline Year of Internet Use $(\mathrm{I})$ & Year of Internet Use $(\mathrm{J})$ & Order Difference & $\mathrm{S}$ & $\mathrm{P}$ \\
\hline 1 year and under & 1-3 year & .91524 & .27049 & .111 \\
& 3-5 year & -.61549 & .26072 & .136 \\
& 5 year and more* & -.85472 & .25419 & .011 \\
1-3 year & 1 year and under* &.-91524 & .27049 & .110 \\
& 3-5 year & -.29975 & .12404 & .121 \\
3-5 year & 5 year and more & -.06052 & .10996 & .959 \\
& 1 year and under & -.61549 & .26072 & .136 \\
& 1-3 year & .29975 & .12404 & .121 \\
5 year and more & 5 year and more* & .23923 & .08267 & .140 \\
& 1 year and under* & .85472 & .25419 & .011 \\
& 1-3 year & .06052 & .10996 & .959 \\
& 3-5 year & -.23923 & .08267 & .040 \\
\hline
\end{tabular}

\subsubsection{Social media usage hoursand social media usage time}

According to the results of One Way Anova test when Table 11 is examined; it was concluded that social media attitudes of Vocational High Schoolstudents had a significant effect according to hours of use ( $p$ $<0.05)$. Post ANOVA Post-Hoc Scheffe Test was used to determine whether there was a difference between the Internet usage time research sub-groups.

Table 11. The effect of social media attitudes of vocational school students on social media usage hour's variable

\begin{tabular}{llllll}
\hline Source of variance & Sum of Squares & sd & Squares Per & F & P \\
\hline Intergroup & 5.987 & 4 & 1.996 & 3.462 & .016 \\
Intra Group & 286.472 & 497 & .576 & & \\
Total & 292.459 & 501 & & & \\
\hline
\end{tabular}

When Table 12 is examined, according to Scheffe test results; when social media usage hours were compared, it was found that there was a significant difference between 1-3 hours and 3-5 hours of internet usage $(\mathrm{p}<0.05)$.

Table 12. Comparison of social media usage time sub-groups

\begin{tabular}{lllll}
\hline Social Media Usage Hours (I) & $\begin{array}{l}\text { Social Media Usage } \\
\text { Hours }(\mathrm{J})\end{array}$ & Order Difference & $\mathrm{S}$ & $\mathrm{P}$ \\
\hline 1 year and under & 1-3 year & .10662 & 0.9793 & .757 \\
& 3-5 year & -.15991 & .10297 & .492 \\
& 5 year and more & -0.8958 & .11052 & .883 \\
1-3 year & 1 year and under &.-10662 & .09793 & .757 \\
& 3-5 year & -.26653 & 0.8675 & .025 \\
3-5 year & 5 year and more & -.19621 & 0.9559 & .241 \\
& 1 year and under & .15991 & .10297 & .492 \\
1-3 year & .26653 & 0.8675 & .025 \\
5 year and more & 5 year and more & .07032 & .10075 & .922 \\
& 1 year and under & .08958 & .11052 & .883 \\
& 1-3 year & .19621 & .09559 & .241 \\
& 3-5 year & -.7032 & .10075 & .922 \\
\hline
\end{tabular}




\subsection{The relationship between social media attitudes with internet connection year of vocational school} students' pearson correlation analysis

According to the analysis, there was a positive, high and significant relationship between social media attitudes of Vocational High School students and internet connection years $(r=.929$ and $\mathrm{p}<0.01)$.

\subsection{The relationship between social media attitudes with social media usage hour of vocational school students' pearson correlation analysis}

According to the analysis, there was a positive, high and significant relationship between the social media attitudes of Vocational High Schoolstudents and social media usage hours $(r=.804$ and $p<0.01)$.

\section{DISCUSSION}

Dikme [9] revealed that university students follow social media with great interest and use it actively as a similar result. Tektaş [24] found that the most frequently used device to connect to the internet is a mobile phone. In their study, Solmaz et al. [25] found that university students use social media extensively and spend approximately 1-3 hours a day in social networks.In addition, the aim of using social media has been revealed to be sharing photos and information, having fun and relaxing, having free time, having information and accessing information. Boateng and Amankwaa [26] researched the effect of social media on students' academic life and as a result, it became clear that social media became a platform where students can communicate effectively with their instructors in higher education institutions. Thus, it was emphasized that thinking skills, cooperation and sharing of knowledge were improved and access to information was facilitated between the trainer and the instructor.

In this study, Social Media Attitude Scale developed by Otrar and Argin [1] was used to determine social media attitudes of Vocational School students.Akuzum and Saracoğlu [27] found that social media attitudes of university students did not differ significantly by gender in their research.However, it was observed that participants who used social media sites for 3-4 years and more than 4 years had higher attitudes to social media than participants who used less than 1 year.

\section{CONCLUSION}

The aim of this study was to investigate the social media attitudes of Vocational High School students, in this context, a total of 502 students from Sakarya University and Kafkas University Vocational Schools were studied. In the study, it was found that the majority of Vocational School students benefited from social networks, had memberships in social networks, and the frequency of using social media was " 4 hours or more. In addition, the majority of students use the device to connect to the internet "computertablet", the purpose of using the Internet is usually "social networks" status, the use of the Internet frequency of use of "5 hours and above", the frequency of having an Internet connection is " 5 hours and above". When the field is examined, these results show that most of today's young people have personal mobile devices and thus have fast access to the internet and therefore information.

In the context of correlating social media attitudes of Vocational High School students with demographic data; There was no significant difference between gender, department, class, internet usage hours, but there was a significant difference between internet connection year and social media usage hours.In terms of internet connection year variable, it is found that there is a significant difference between 1 year and 5 connection years and 5 years and above connection years.In terms of social media usage time variable; there was a significant difference between 1-3 hours and 3-5 hours. The general average of all items was determined according to the answers given by the Vocational High School students to the scale items and it was concluded that the answers were generally "undecided". In addition, the highest average substance; "I like to share the posts I see on social media sites with my friends as a chat topic" the lowest average substance; "I think social media sites have taken me away from my family".

In this study, Pearson Correlation analysis was used to determine the relationship between the variable structures in question. Accordingly, a positive and high-level relationship was found between the social media attitudes with internet connection year of Vocational High School students and internet connection years. Similarly also, positive and high level relationship was determined between students' social media attitudes with social media usage hours.

\section{REFERENCES}

[1] Otrar, M. ve Argın, F. S., "Öğrencilerin sosyal medyaya ilişkin tutumlarını belirlemeye yönelik bir ölçek geliştirme çalışması," Eğitim ve Öğretim Araştırmaları Dergisi, Cilt 4, Sayı vol. 1(37), 2015. 
[2] Kalafatoğlu Y., (2011), Sosyal Medya ve E-Pazarlama İlişkisi, [online] [avalaible] http://sosyomedya.org/2011/04/01/sosyal-medya-ve-e-pazarlama-ile-iliskisi/date of access: 01.06.2019.

[3] Erkul, R. E., "Sosyal medya araçlarının (web 2.0) kamu hizmetleri ve uygulamalarında kullanılabilirliğ". Türkiye Bilişim Derneği Dergisi, (116), pp. 96-101, 2009.

[4] Comm, J. And Burge, K., TwitterPower, How to DominateYour Market OneTweet at a Time, Published by John Wiley\&SonsInc, New Jersey, 2009.

[5] Kim, W., Jeong, O-R., Lee, S-W., on social web sites, information systems, vol. 35, pp. 215-236, 2010.

[6] Murray, C., "Schools and social networking: fearoreducation? Synergy perspectives: local," vol. 6(1), pp. 8-12, 2008.

[7] Paul, M. J., Dredze, M., "You are what you tweet: Analyzing twitter for public health," Icwsm, vol. 20, pp. 265-272, 2011.

[8] Akar, E., Sosyal Medya Pazarlaması. İstanbul: Elif Yayınevi, 2010.

[9] Dikme, G., "Üniversite öğrencilerinin iletişimde ve günlük hayatta sosyal medya kullanım alışkanlıkları: Kadir has üniversitesi örneği," Kadir Has Üniversitesi Sosyal Bilimler Enstitüsü, İstanbul, master's thesis, 2013.

[10] Üksel, S., "Kullanımlar ve doyumlar kuramı çerçevesinde sosyal medya kullanımı: sakarya üniversitesi öğrencileri üzerine bir araştırma," Selçuk Üniversitesi Sosyal Bilimler Enstitüsü, Konya, master's thesis, 2015.

[11] Tutgun-Ünal, A., "Sosyal medya bağımlılı̆̆ı: Üniversite öğrencileri üzerine bir araştırma. Marmara Üniversitesi Sosyal Bilimler Enstitüsü," İstanbul, master's thesis, 2015.

[12] Karal, H and Kokoç, "M. Üniversite öğrencilerinin sosyal ağ siteleri kullanım amaçlarını belirlemeye yönelik bir ölçek geliştirme çalışması," Turkish Journal of Computer and Mathematics Education, vol. 1(3), pp. 251-263, 2010.

[13] Mayfield, A. (2008). What is Social Media, An e-book by Antony Mayfield from iCrossing, [online available] (Erişim:http://www.icrossing.co.uk/fileadmin/uploads/eBooks/What_is_Social_Media_iCrossing_ebook.pdf adresinden 15.05.2015 tarihinde indirildi).

[14] Öztürk, M. F., Talas, M., "Sosyal medya ve eğitim etkileşimi," Zeitschrift für die Welt der Türken Journal of World of Turks, vol. 7(1); pp. 112-113, 2015.

[15] Aydın, İ. E., "Üniversite öğrencilerinin sosyal medya kullanımları üzerine bir araştırma: anadolu üniversitesi örneği," Selçuk Üniversitesi Sosyal Bilimler Enstitüsü Dergisi, vol. (35), pp. 373-386, 2016.

[16] Park, N., Kee, and K. F. ve Valenzuela, S. "Being immersed in social networking environment: Facebook groups, uses and gratifications, and social outcomes," CyberPsychology \& Behavior, C.12, S.6, ss. pp. 729-733, 2009.

[17] Biçer, S., "Akademisyenlerin sosyal ağlarda bulunma motivasyonları: facebook örneği," Dumlupınar Üniversitesi Sosyal Bilimler Dergisi, S.40,s. pp. 59-80, 2014.

[18] Koçak, G., "Bireylerin sosyal medya kullanım davranışlarının ve motivasyonlarının kullanımlar ve doyumlar yaklaşımı bağlamında incelenmesi: Eskisehir de bir uygulama," Anadolu Üniversitesi Sosyal Bilimler Enstitüsü, doctoral thesis, Eskişehir, 2012.

[19] Çam, E. ve İşbulan, O., "A new addiction for teacher candidates: Social networks," The Turkish Online Journal of Educational Technology (TOJET), vol. 11(3), pp. 14-19, 2012.

[20] Eraslan, L, "Sosyal medyayı anlamak," Ankara: Nobel Yaşam Yayınları, 2016.

[21] Buglass, S.L., Binder, J.F., Betts, L.R. and Underwood, J.D.M., "Motivators of online vulnerability: the impact of social network site use and fomo," Computers In Human Behavior, 66, pp. 248-255, 2017.

[22] Karasar, N., "Bilimsel araştırma yöntemleri," Nobel Yayıncılık, Ankara, .2013.

[23] Büyüköztürk, Ş., "Bilimsel araştırma yöntemleri," PegemAAkademi, Ankara, 2013.

[24] Tektaş, N., "Üniversite öğrencilerinin sosyal ağları kullanımlarına yönelik bir araştırma," Tarih Okulu Dergisi (TOD), XVII, pp. 851-870, 2014.

[25] Solmaz, B., Tekin, G. Herzem, Z. ve Demir, M. "Internet ve sosyal medya kullanımı üzerine bir uygulama," Selçuk Illetişim, 7, 4, syf. pp. 24-32, 2013.

[26] Boateng, R. ve Amankwaa, "A. the impact of social media on student academic life in higher education," Global Journal of Human-Social Science: Glinguistics \& Education, Vol. 16(4), Version 1.0, 2016.

[27] Aküzüm, C. ve Saraçoğlu, M., "Üniversite öğrencilerinin sosyal medyaya ilişkin tutumlarınınincelenmesi," Dicle Üniversitesi Eğitim Fakültesi Dergisi, Sayı 32, pp. 803-817, 2017. 